\title{
Sciendo
}

Acta Veterinaria-Beograd 2019, 69 (3), 312-324

UDK: 591.2:599.742.17:616.993.1(497.11)

DOI: 10.2478 /acve-2019-0026

Research article

\section{CANDIDATUS NEOEHRLICHIA SP. (FU98) AND BORRELIA BURGDORFERI SENSU LATO IN RED FOXES (VULPES VULPES) FROM SERBIA}

\author{
SUKARA Ratko ${ }^{1}$, JUWAID Salem², ĆIROVIĆ Duško², PENEZIĆ Aleksandra², \\ MIHALJICA Darko ${ }^{1}$, VEINOVIĆ Gorana ${ }^{1}$, RADOJIČIĆ Sonja ${ }^{3}$, HODŽIĆ Adnan ${ }^{4}$, \\ DUSCHER Gerhard Georg ${ }^{4}$, TOMANOVIĆ Snežana ${ }^{1 *}$
}

\begin{abstract}
${ }^{1}$ Group for Medical Entomology, Center of Excellence for Food and Vector-borne Zoonoses, Institute for Medical Research, University of Belgrade, Belgrade, Serbia; ${ }^{2}$ Faculty of Biology, University of Belgrade, Belgrade, Serbia; ${ }^{3}$ Department of Infectious Animals Diseases and Diseases of Bees, Faculty of Veterinary Medicine, University of Belgrade, Belgrade, Serbia; ${ }^{4}$ Institute of Parasitology, Department of Pathobiology, University of Veterinary Medicine Vienna, Vienna, Austria
\end{abstract}

(Received 18 April, Accepted 23 August 2019)

Human activities such as deforestation, urbanization, and environmental pollution lead to a reduction in the spatial boundary between wild animals, domestic animals and humans. These activities increase the risk for the emergence of pathogens from the sylvatic cycle in the population of domestic animals and humans. Foxes are recognized as potential reservoirs for a number of bacterial pathogens of medical and public health concern. The aim of the present study was to investigate the prevalence and spatial distribution of bacterial tick-borne pathogens from the Anaplasmataceae family, Borrelia burgdorferi sensu lato (s.l.), Rickettsia spp., Coxiella burnetii, Francisella tularensis, Bartonella spp., in the red fox population from Serbia and to discuss the obtained results from the epidemiological point of view. Legally hunted red foxes (Vulpes vulpes) from 14 localities in Serbia were included in the study and spleen samples from 129 animals were tested with conventional PCR assays for the presence of bacterial tick-borne pathogens. DNA of Candidatus Neoehrlichia sp. (FU98), Borrelia burgdorferi sensu stricto, Borrelia lusitaniae, and Borrelia garinii was detected in $6(4.7 \%), 1(0.8 \%), 2(1.6 \%)$ and $1(0.8 \%)$ animals, respectively. Co-infection by Candidatus Neoehrlichia sp. (FU98) and B. garinii was detected in one animal. All samples were negative for other tested bacterial tickborne pathogens. The results of the present study indicate the potential role of foxes in natural cycles of Candidatus Neoehrlichia sp. (FU98) and causative agents of Lyme borreliosis in the investigated areas. Further research is required to elucidate the role of foxes in the epidemiology of these and other tick-borne zoonotic pathogens in the Republic of Serbia.

Key words: Anaplasmataceae, Borrelia spp., Candidatus Neoehrlichia sp. (FU98), foxes, PCR, Serbia

\footnotetext{
*Corresponding author: e-mail: snezanat@imi.bg.ac.rs
} 


\section{INTRODUCTION}

The spatial boundary between wild canids, humans and domestic animals in the past decades has been greatly reduced due to degradation and fragmentation of the habitat caused by anthropogenic activities such as development of agriculture, deforestation, urbanization and environmental pollution [1]. These changes have led to the possibility of the emerging and re-emerging of diseases in human and domestic animals' population caused by pathogens that are maintained in wild canids [2]. The number of diseases originating in the wildlife are arthropod-borne and among arthropods, ticks are along with mosquitoes the most significant vectors of zoonotic diseases $[3,4]$.

In recent years, researchers pointed out the possible role of red foxes (Vulpes vulpes) in the epizootiology of bacterial tick-borne diseases (TBDs) [5,6]. The presence of several tick-borne pathogens from the Anaplasmataceae family was detected among foxes in Europe: Anaplasma phagocytophilum, a causative agent of granulocytic anaplasmosis in humans and animals [7-9], Anaplasma platys, an etiologic agent of thrombocytic anaplasmosis in dogs [10], and Ehrlichia canis that causes monocytic ehrlichiosis in canids [11,12]. Recently, the role of foxes as potential reservoirs for the newly discovered member of the family Anaplasmataceae, Candidatus Neoehrlichia sp., (FU98) has been proposed [13]. Foxes are also recognized as reservoir hosts for the causative agents of Lyme borreliosis, spirochetes from the Borrelia burgdorferi sensu lato complex (s.l.) [14]. Molecular studies conducted in Europe, did not show the presence of Rickettsia spp. in red fox [11,15,16], although the presence of Rickettsia spp. in ticks collected from red foxes has been proved $[17,18]$ and serological studies confirmed that foxes are exposed to those zoonotic pathogens [17]. The most commonly detected Bartonella species in European foxes is zoonotic Bartonella rochalimae [19-23]. A recently published serosurvey indicates that foxes are suitable hosts for Francisella tularensis, the causative agent of tularemia in humans and animals [24]. High seroprevalence rate $(41.2 \%)$ of Coxiella burnetii was detected in red foxes in the United Kingdom [25]. Furthermore, foxes are hosts for a number of vectors of the above mentioned pathogens; ticks from four genera are found to parasitize red foxes in Europe (Ixodes ricinus, I. canisuga, I. bexagonus, Dermacentor reticulatus, D. marginatus, Haemaphysalis concinna, H. punctata, H. inermis, H. erinacei, Rhipicephalus bursa, R. sanguineus, R. turanicus) [26-29]. The results of previous studies and insufficient knowledge on the role of foxes in the eco-epidemiology of bacterial tick-borne pathogens justify further research. The red fox is one of three native canid species present in Serbia. The range of foxes covers the whole territory of the country and they are the most abundant medium-sized predators [30]. Abundant population, frequent infestation with various tick species and close contact with humans and domestic animals impose the need to explore the exact role of foxes in enzootic cycles of TBDs in a particular area. Based on the studies on ectoparasite fauna of red foxes in Serbia, the presence of nine hard tick species were reported, namely: I. ricinus, I. hexagonus, I. canisuga, R. sanguineus, R. bursa, $H$. punctata, H. inermis, D. marginatus and D. reticulatus $[31,32]$. However, research on the 
role of foxes as potential vectors and reservoirs for tick-borne pathogens in this area has not been carried out so far. The aim of the present study was to investigate the presence of bacterial tick-borne pathogens in the fox population from Serbia and to discuss the obtained results from the epidemiological point of view.

\section{MATERIALS AND METHODS}

In total, 129 legally hunted red foxes from 14 localities in Serbia (Surčin, Obrenovac, Veliko Gradište, Velika Plana, Svilajnac, Negotin, Despotovac, Rekovac, Kraljevo, Vrnjačka Banja, Trstenik, Blace, Niš, Bela Palanka) were included in the study (Figure 1). Samples were collected over a period of seven years (2010-2016). Date of sampling,

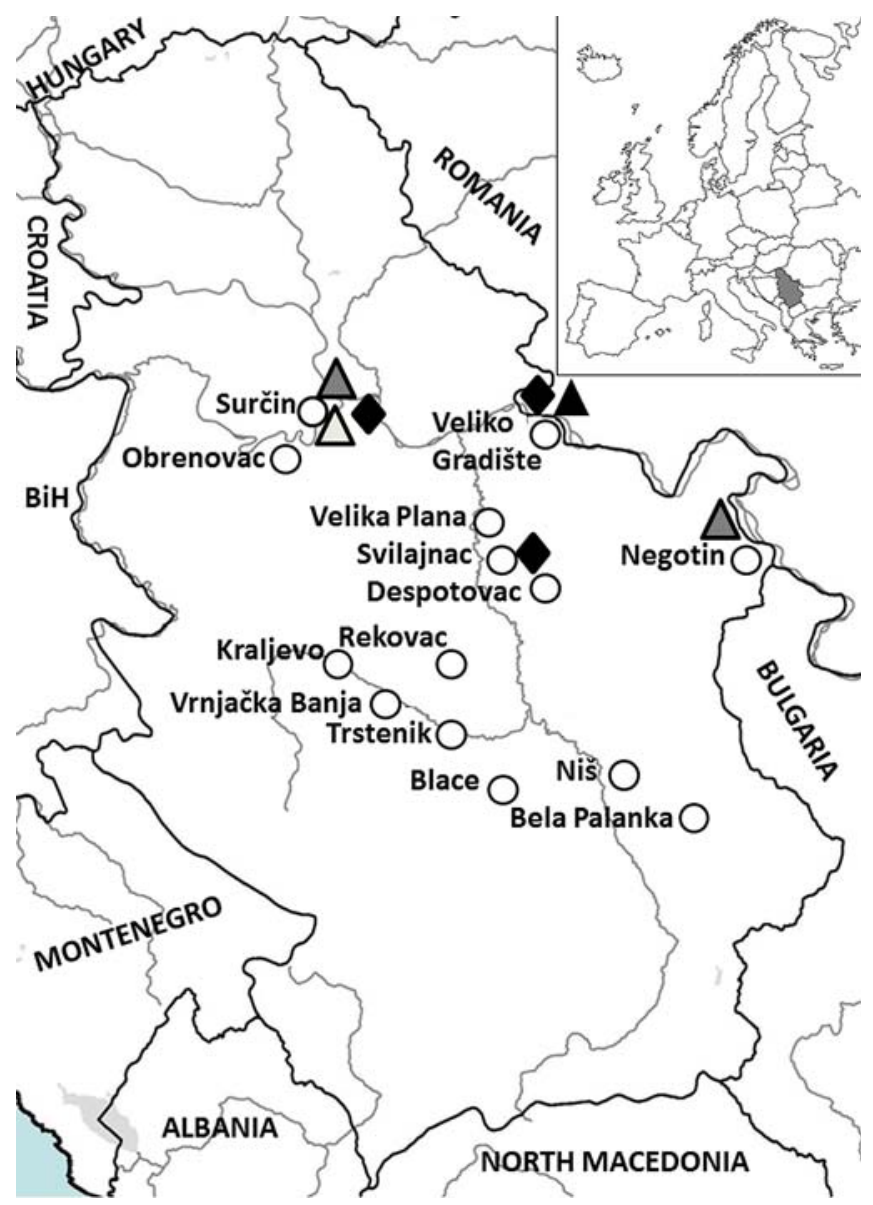

Figure 1. Geographical distribution of positive foxes for DNA of Candidatus Neoehrlichia sp. (FU98), and Borrelia spp.

- Candidatus Neoehrlichia sp. (FU98), (localities: Surčin, Veliko Gradište, and Svilajnac), - Borrelia burgdorferi sensu stricto, (locality Veliko Gradište), $\triangle$ - Borrelia lusitaniae, (localities: Surčin and Negotin), $\triangle$ - Borrelia garinii (locality Surčin). 
sex and origin of the animals were recorded. Spleen samples were collected from the necropsied animals and the cold chain was provided for transfer of the tissue samples to the laboratory. Prior to DNA extraction samples were stored at $-80^{\circ} \mathrm{C}$. DNA extraction was performed using the Gene Jet Genomic DNA Purification Kit (Fermentas, Thermo Scientific). A small portion of spleen tissue (up to $10 \mathrm{mg}$ ) was homogenized by micropestles (Eppendorf ${ }^{\mathrm{TM}}$ ), and extraction was carried out according to the manufacturer's instruction. The extracted DNA was placed at $-20^{\circ} \mathrm{C}$ until PCR analyses.

\section{PCR assay}

In order to detect the DNA of tested pathogens, previously published conventional PCR protocols were used (Table 1).

The PCR reactions for detection of B. burgdorferi s.l., Rickettsia spp., C. burnetii, F. tularensis, Bartonella spp. and members of the family Anaplasmataceae were prepared using PCR Master Mix (2X) (Thermo Fisher Scientific Inc.). Amplification of targeted sequences was performed using Veriti Thermal Cycler device (Applied Biosystems). PCR products were electrophoresed on 2\% agarose gel stained with Ethidium Bromide and visualized using BioDocAnalyze device (Biometra $\mathrm{GmbH}$ ). Detection of Candidatus Neoehrlichia spp. and preparation of positive samples for sequencing was performed with GoTaq ${ }^{\circledR}$ G2 Polymerase (Promega, USA).

\section{Sequencing and sequence analysis}

The purification and bidirectional sequencing (Sanger) of obtained PCR products were performed by commercial companies (Macrogen, Amsterdam, the Netherlands and Microsynth, Austria). Sequences were compared with previously published nucleotide sequences available in the GenBank ${ }^{\circledR}$ database using the BLAST tool (National Center for Biotechnology Information) (http://www.ncbi.nlm.nih.gov/BLAST), analysed using the FinchTV v1.5.0, software and aligned using Clustal W.

Representative sequences from this study have been deposited to the GenBank ${ }^{\circledR}$ database under the following accession numbers: MK043348 (16S rRNA), MK050781 (groEL) - Candidatus Neoehrlichia sp. (FU98), MK043031 - Borrelia burgdorferi sensu stricto (s.s.), MK043032 - Borrelia garinii, MK043041 - Borrelia lusitaniae.

\section{Statistical analysis}

Confidence intervals $(95 \% \mathrm{CI})$ were calculated using the online calculator available at http://vassarstats.net/prop1.html. 


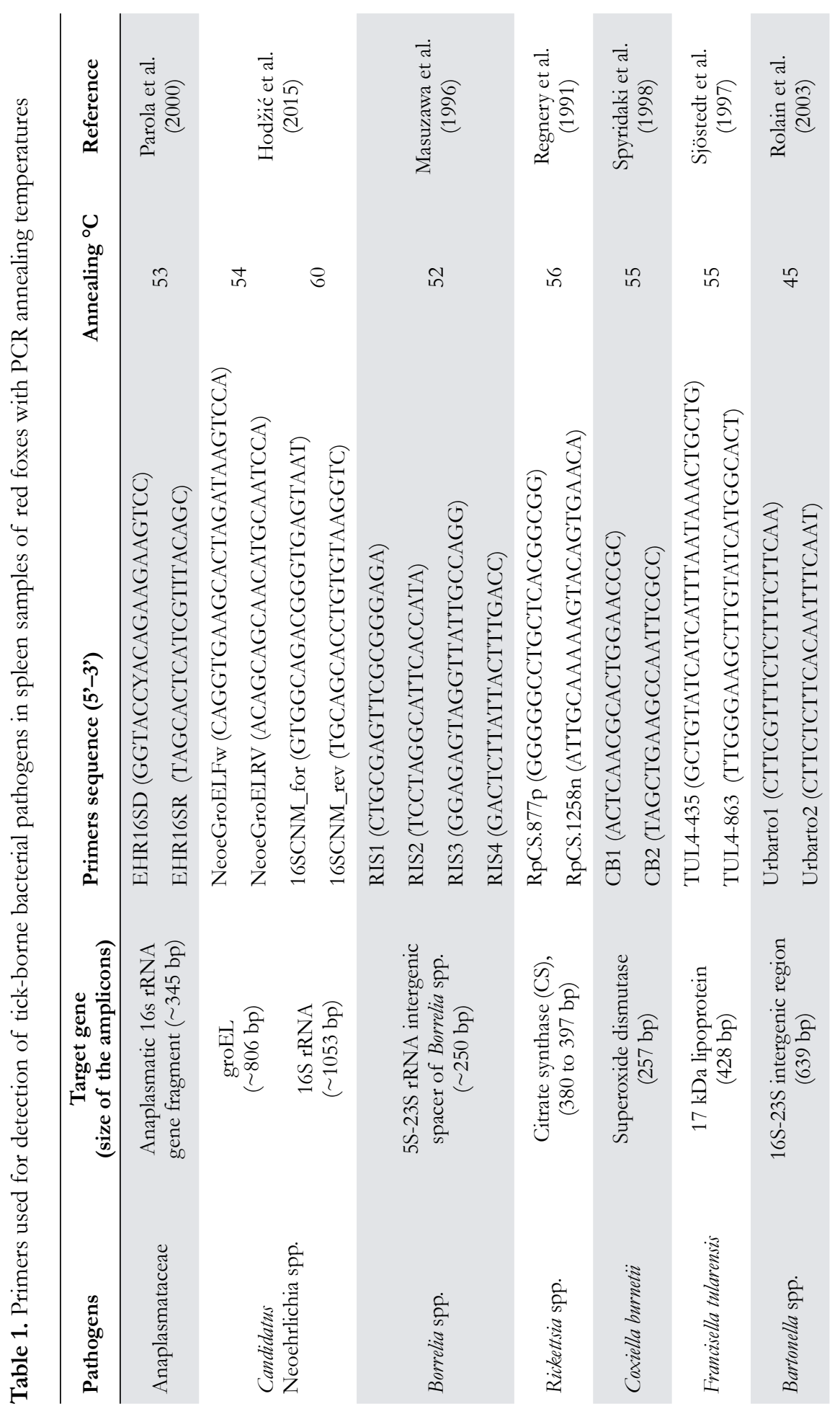




\section{RESULTS}

Sampling from 129 animals ( 73 males and 56 females) preceded analysis procedures. The majority of samples originated from three locations - Veliko Gradište ( $\mathrm{n}=45$ animals), Surčin $(n=29)$ and Svilajnac $(n=13)$ while remaining localities were represented with fewer samples.

DNA of the members of family Anaplasmataceae and B. burgdorferi s.l. was detected among analyzed spleen samples, while the presence of DNA of other tested bacterial pathogens (Rickettsia spp., Bartonella spp., C. burnetii and F. tularensis) was not confirmed. DNA of the members of B. burgdorferi s.l. complex was detected in 7 samples [(5.4\%), 95\% CI: $2.7-10.8 \%$. originated from 2/73 (2.7\%) male and 5/56 (8.9\%) female animals collected from 3 localities (Surčin, Obrenovac, Veliko Gradište). Sequencing of 5S-23S rRNA intergenic spacer region was successful for four samples and analysis of the obtained sequences confirmed the presence of three B. burgdorferi s.l. species, namely: B. burgdorferi s.s. (locality Veliko Gradište), B. lusitaniae (localities Surčin and Negotin) and B. garinii (locality Surčin), (Figure 1).

Molecular detection with primers specific for 16S rRNA gene fragment ( $345 \mathrm{bp}$ ) of the family Anaplasmataceae showed positive bands in 21 animals, and these samples were preceded for sequencing for initial screening. Obtained sequences were compared with previously published sequences deposited at the GenBank ${ }^{\circledR}$, and 8 sequences showed partial coverage with 93-99\% similarity with Candidatus Neoehrlichia spp. sequences. These samples were further tested with primers specific for longer fragments of groEL ( $806 \mathrm{bp})$ and 16S rRNA ( 1053 bp) genes of Candidatus Neoehrlichia spp. Amplification was successful for 6/129 samples, [(4.7\%), 95\% CI: $2.2-9,8 \%$ ] originating from $4 / 73(5.5 \%)$ male and 2/53 (3.8\%) female animals hunted at three out 14 localities: Surčin, Veliko Gradište, and Svilajnac (Figure 1). Positive samples were thereon sequenced. The sequences of Candidatus Neoehrlichia sp. (groEL and $16 \mathrm{~S}$ rRNA), obtained in this study showed $100 \%$ similarity to the sequences of Candidatus Neoerlichia sp. (FU98) from red foxes from Austria (GenBank ${ }^{\circledR}$ accession numbers: KT833357, KT833358), from raccoon dogs (Nyctereutes procyonoides) from Poland (MG670107, MG670109) and from a badger (Meles meles) from Hungary (KX245423, KX231830). Also, researchers from Hungary have recently confirmed the presence of Candidatus Neoehrlichia sp. (FU98) in rural dogs [33]. The sequences were identical to the sequences that have been previously obtained from badgers in this country (KX245423, KX231830).

Despite relatively low prevalence of pathogens, co-infection of Candidatus Neoehrlichia sp. (FU98) and B. garinii was detected in one male fox $(0.8 \%)$ hunted at the locality of Surčin. 


\section{DISCUSSION}

Presented study is the first one that investigates red foxes as hosts of bacterial tickborne pathogens in Serbia. Based on the obtained results, the potential role of foxes in natural cycles of Candidatus Neoehrlichia sp. (FU98) and B. burgdorferi s.l. complex in the investigated area was discussed. Two species are currently proposed to be classified in the Anaplasmataceae family: Neoebrlichia mikurensis (Nm) and Candidatus Neoehrlichia lotoris $(\mathrm{CNl}) . \mathrm{Nm}$ is a recently cultured [34] emerging tick-borne zoonotic pathogen, identified for the first time in ticks from the Netherlands [35] and small mammals from China [36]. The first human case was detected in Sweden in 2010 [37]. I. ricinus is considered as the main vector in Europe and rodents are suggested as reservoirs [38]. Another agent closely related to $\mathrm{Nm}$ was detected for the first time in raccoons (Procyon lotor) in North America [39] and then successfully isolated from tick cells lines. Based on phylogenetic analysis of three genes $(16 S \mathrm{rRN} A$, groEL, glt $A)$ it was clear that the new agent is distinct from $\mathrm{Nm}$ and it was named $\mathrm{CNl}$ [40]. Experimental infection of raccoons with $\mathrm{CNl}$ was successfully demonstrated while infection of laboratory rodents failed [41]. It is believed that the ticks of the genus Ixodes are the main vectors.

A newly discovered sequence type FU98, phylogenetically closely related to $\mathrm{CN1}$, but clearly distinct from $\mathrm{Nm}$ previously isolated from various hosts in Europe, was detected for the first time in Austrian foxes [23,42]. It has been also confirmed in one fox from the Czech Republic [43]. The present study brings evidence toward a wider distribution of this potentially new bacterial species in foxes in Europe, while further research is needed to investigate the exact role of foxes in the epizootiology of Candidatus Neoehrlichia sp. (FU98). Due to its genetic similarity to $\mathrm{CN}$ isolated from raccoons in North America, the hypothesis that a newly discovered sequence type was introduced to Europe with raccoons and spilled over to foxes should be validated. Recently, Candidatus Neoehrlichia sp. (FU98) was detected in a raccoon dog from Poland [44] and in a badger from Hungary [45]. The latest finding of Hornok et al., (2018) reports the presence of a strain similar to Candidatus Neoehrlichia sp. (FU98) in dogs from Hungary. The aforementioned findings raise the possibility that more mammalian species are susceptible hosts for this new strain type and make the epizootiological situation more complex. Presence of free-ranging raccoons, raccoon dogs and badgers has been reported on the territory of the Republic of Serbia $[46,47]$, however studies concerning the role of the mentioned animals in the epidemiology of tick-borne bacterial pathogens in Serbia have not so far been carried out. Future research concerning Candidatus Neoehrlichia sp. (FU98) should be directed toward the detection of the presence and determination of the pathogenic potential in different hosts and to more integrated epidemiological studies in order to evaluate previous findings from the standpoint of human and veterinary medicine.

Borrelia burgdorferi s.l. circulates in nature through enzootic cycles that involve different vertebrate hosts and ticks as vectors, with $I$. ricinus recognized as the main vector in Europe [48]. Data on the prevalence of B. burgdorferi s.l. in foxes in Europe are 
scarce, although it has been previously shown that foxes may serve as competent reservoirs for B. burgdorferi s.l. [14,49]. German researchers detected DNA of $B$. burgdorferi s.l. in the skin of foxes in two separate studies, with prevalences of $7 \%$ and $24 \%$, respectively [14,50]. In Romania, the prevalence of B. burgdorferi s.l. in analyzed heart tissue of foxes was $1.42 \%$ [51]. Previous serosurveys in Serbia have shown the exposure of dogs to B. burgdorferi s.l. [52,53], while data on the diversity of B. burgdorferi s.l. species in $I$. ricinus ticks collected from the vegetation across the country, indicate the presence of the following five species: B. burgdorferi s.s., Borrelia afzelii, B.lusitaniae, B.garinii and Borrelia valaisiana [54,55]. Prevalence of B.burgdorferi s.l. detected in foxes in our study $(5.4 \%)$ is in the range of previously published data for Europe, however it is the first record of Borrelia spirochetes in spleen samples of red foxes. Among analyzed samples, the presence of three Borrelia species was confirmed: B. burgdorferi s.s., B. lusitaniae and B. garinii. These pathogens were confirmed for the first time in foxes from Serbia. B. burgdorferi s.s. and B. garinii are proven causative agents of Lyme borreliosis while pathogenicity of B. lusitanae is still unclear [56]. Further studies are needed to elucidate the exact role of foxes in the epidemiology of zoonotic Borrelia spp., detected in the present study. Detected co-infection with Candidatus Neoehrlichia sp. (FU98) and B. garinii in one fox represents a basis for assuming the possibility for overlapping of natural cycles of these two pathogens. Previous research has shown that questing I. ricinus ticks from Serbia are co-infected with several tick-borne bacterial pathogens [54,55] although the co-infection with Candidatus Neoehrlichia sp. (FU98) and B. garinii has not been proven in ticks so far. The significance of this finding from the epidemiological aspect remains to be defined in future studies.

\section{CONCLUSION}

Candidatus Neoehrlichia sp. (FU98) and B. burgdorferi s.l. were detected for the first time in the spleen of foxes from Serbia. Obtained results indicate to the potential role of foxes as a reservoir for Candidatus Neoehrlichia sp. (FU98) and causative agents of Lyme borreliosis. Further research is needed to reveal the importance of foxes in the eco-epidemiology of these and other tick-borne pathogens in Serbia.

\section{Acknowledgment}

This publication was supported by a grant from the Ministry of Education, Science and Technological Development of Republic of Serbia (Project No. OI173006) and represents a collaborative effort of Serbian and Austrian researchers formalized through a bilateral project 451-03-01039/2015-09/10.

\section{Authors' contributions}

RS carried out the molecular genetic studies, participated in the sequence analysis and drafted the manuscript, SJ carried out the molecular genetic studies, AH carried out part of the molecular genetic studies, participated in the sequence analysis, AP 
provided valuable samples for the study, DĆ provided valuable samples for the study and critically revised the manuscript, DM and GV conducted statistical analysis, SR and GD critically revised the manuscript, ST initiated and supervised the study, coordinated the activities and helped to draft the manuscript. All authors read and approved the final manuscript.

\section{Declaration of conflicting interests}

The author(s) declared no potential conflicts of interest with respect to the research, authorship, and/or publication of this article.

\section{REFERENCES}

1. Aguirre AA: Wild canids as sentinels of ecological health: a conservation medicine perspective. Parasit Vectors 2009, 2 (Suppl 1):S7.

2. Tomassone L, Berriatua E, De Sousa R, Duscher GG, Mihalca AD, Silaghi C, Sprong H, Zintl A: Neglected vector-borne zoonoses in Europe: Into the wild. Vet Parasitol 2018, 251:17-26.

3. Jongejan F, Uilenberg G: The global importance of ticks. Parasitology 2004, 129:S3-14.

4. Colwell DD, Dantas-Torres F, Otranto D: Vector-borne parasitic zoonoses: Emerging scenarios and new perspectives. Vet Parasitol 2011, 182:14-21.

5. Duscher GG, Fuehrer H-P, Kübber-Heiss A: Fox on the run - molecular surveillance of fox blood and tissue for the occurrence of tick-borne pathogens in Austria. Parasit Vectors 2014, 7:521.

6. Otranto D, Cantacessi C, Pfeffer M, Dantas-Torres F, Brianti E, Deplazes P, Genchi C, Guberti V., Capelli G: The role of wild canids and felids in spreading parasites to dogs and cats in Europe. Vet Parasitol 2015, 213:12-23.

7. Ebani VV, Verin R, Fratini F, Poli A, Cerri D: Molecular survey of Anaplasma phagocytophilum and Ehrlichia canis in red foxes (Vulpes vulpes) from central Italy. J Wildl Dis 2011, 47:699_ 703.

8. Hulinska D, Langrova K, Pejcoch M, Pavlasek I: Detection of Anaplasma phagocytophilum in animals by real-time polymerase chain reaction. Apmis 2004, 112:239-247.

9. Härtwig V, von Loewenich FD, Schulze C, Straubinger RK, Daugschies A, Dyachenko V: Detection of Anaplasma phagocytophilum in red foxes (Vulpes vulpes) and raccoon dogs (Nyctereutes procyonoides) from Brandenburg, Germany. Ticks Tick Borne Dis 2014, 5:277-80.

10. Cardoso L, Gilad M, Cortes, H, Nachum-Biala Y, Lopes A, Vila-Viçosa M, Simões M, Rodrigues PA, Baneth G: First report of Anaplasma platys infection in red foxes (Vulpes vulpes) and molecular detection of Ehrlichia canis and Leishmania infantum in foxes from Portugal. Parasit Vectors 2015, 8:144.

11. Torina A, Blanda V, Antoci F, Scimeca S, D’Agostino R, Scariano E, Piazza A, Galluzzo P, Giudice E, Caracappa S: A Molecular Survey of Anaplasma spp., Rickettsia spp., Ebrlichia canis and Babesia microti in Foxes and Fleas from Sicily. Transbound Emerg Dis 2013, 60:125-130.

12. Santoro M, Veneziano V, D’Alessio N, Di Prisco F, Lucibelli MG, Borriello G, Cerrone A, Dantas-Torres F, Latrofa MS, Otranto D, Galiero G: Molecular survey of Ehrlichia canis and Coxiella burnetii infections in wild mammals of southern Italy. Parasitol Res 2016, 115:4427-31. 
13. Hodžić A, Cézanne R, Duscher GG, Harl J, Glawischnig W, Fuehrer HP: Candidatus Neoehrlichia sp. in an Austrian fox is distinct from Candidatus Neoehrlichia mikurensis, but closer related to Candidatus Neoehrlichia lotoris. Parasit Vectors 2015, 8:539.

14. Liebisch G, Dimpfl B, Finkbeiner-Weber B, Liebisch A, Frosch M: The red fox (Vulpes vulpes) a reservoir competent host for Borrelia burgdorferi sensu lato. In: Proc 2nd Int Conf Tick-Host-Pathogen Interactions 1995, p.238

15. Boretti FS, Perreten A, Meli ML, Cattori V, Willi B, Wengi N, Hornok S, Honegger H, Hegglin D, Woelfel R, Reusch CE, Lutz H, Hofmann-Lehmann R: Molecular investigations of Rickettsia helvetica infection in dogs, foxes, humans, and Ixodes ticks. Appl Environ Microbiol 2009, 75:3230-7.

16. Hodžić A, Alić A, Fuehrer H-P, Harl J, Wille-Piazzai W, Duscher G. A molecular survey of vector-borne pathogens in red foxes (Vulpes vulpes) from Bosnia and Herzegovina. Parasit Vectors 2015, 8:88.

17. Ortuño A, Sanfeliu I, Nogueras MM, Pons I, López-Claessens S, Castellà J, Antón E, Segura F: Detection of Rickettsia massiliae/Bar29 and Rickettsia conorii in red foxes (Vulpes vulpes) and their Rhipicephalus sanguineus complex ticks. Ticks Tick Borne Dis 2018, 9:629-631.

18. Chisu V, Leulmi H, Masala G, Piredda M, Foxi C, Parola P: Detection of Rickettsia hoogstraalii, Rickettsia belvetica, Rickettsia massiliae, Rickettsia slovaca and Rickettsia aeschlimannii in ticks from Sardinia, Italy. Ticks Tick Borne Dis 2017, 8:347-52.

19. Gerrikagoitia X, Gil H, García-Esteban C, Anda P, Juste RA, Barral M: Presence of Bartonella species in wild carnivores of Northern Spain. Appl Environ Microbiol 2012,78:885-8.

20. Henn JB, Chomel BB, Boulouis HJ, Kasten RW, Murray WJ, Bar-Gal GK, King R, Courreau JF, Baneth G: Bartonella rochalimae in raccoons, coyotes, and red foxes. Emerg Infect Dis 2009, 15:1984-7.

21. Marciano O, Gutiérrez R, Morick D, King R, Nachum-Biala Y, Baneth G, Harrus S: Detection of Bartonella spp. in wild carnivores, hyraxes, hedgehog and rodents from Israel. Parasitology 2016, 143:1232-42.

22. Millán J, Proboste T, Fernández de Mera IG, Chirife AD, de la Fuente J, Altet L: Molecular detection of vector-borne pathogens in wild and domestic carnivores and their ticks at the human-wildlife interface. Ticks Tick Borne Dis 2016, 7:284-90.

23. Hodžic A, Mrowietz N, Cézanne R, Bruckschwaiger P, Punz S, Habler VE, Tomsik V, Lazar J, Duscher GG, Glawischnig W, Fuehrer HP: Occurrence and diversity of arthropodtransmitted pathogens in red foxes (Vulpes vulpes) in western Austria, and possible vertical (transplacental) transmission of Hepatozoon canis. 2018, Parasitology 145:335-344.

24. Otto P, Chaignat V, Klimpel D, Diller R, Melzer F, Müller W, Tomaso H: Serological Investigation of Wild Boars (Sus scrofa) and Red Foxes (Vulpes vulpes) As Indicator Animals for Circulation of Francisella tularensis in Germany. Vector-Borne Zoonotic Dis 2014, 14:4651.

25. Meredith AL, Cleaveland SC, Denwood MJ, Brown JK, Shaw DJ: Coxiella burnetii (Q-Fever) Seroprevalence in Prey and Predators in the United Kingdom: Evaluation of Infection in Wild Rodents, Foxes and Domestic Cats Using a Modified ELISA. Transbound Emerg Dis 2015, 62:639-49.

26. Hinaidy HK: Die Parasitenfauna des Rotfuchses, Vulpes vulpes (L.), in Österreich. Zentralblatt für Veterinärmedizin R B. 1971, 18:21-32.

27. Hinaidy HK. Ein weiterer Beitrag zur Parasitenfauna des Rotfuchses, Vulpes vulpes (L.), in Österreich. Zentralblatt für Veterinärmedizin R B. 1976, 23:66-73. 
28. Sréter T, Széll Z, Varga I: Spatial distribution of Dermacentor reticulatus and Ixodes ricinus in Hungary: Evidence for change? Vet Parasitol 2005, 128:347-51.

29. Lorusso V, Lia RP, Dantas-Torres F, Mallia E, Ravagnan S, Capelli G, Otranto D: Ixodid ticks of road-killed wildlife species in southern Italy: New tick-host associations and locality records. Exp Appl Acarol 2011, 55:293-300.

30. Ćirović D: Morphological variability and biogeorarphical status of the red fox populations (Vulpes vulpes Linnaeus, 1758) in Vojvodina. Faculy of Biology University of Belgrade 2000.

31. Tomanović S, Radulović Ž, Ćakić S, Mihaljica D, Sukara R, Penezić A, Burazerović J, Cirović D: Tick species (acari: Ixodidae) of red foxes (Vulpes vulpes) in Serbia. 2nd Int Symp Hunting Modern Asp Sustain Manag game Popul Novi Sad 2013, 229-235.

32. Pavlović I, Milutinović M, Radulović Ž. Fauna artropoda ektoparazita lisica (Vulpes vulpes L.) u Srbiji. Zb Rezim skupa Entomol Srb Goč 2001, p45.

33. Hornok S, Horváth G, Takács N, Farkas R, Szőke K, Kontschán J: Molecular evidence of a badger-associated Ebrlichia sp., a Candidatus Neoehrlichia lotoris-like genotype and Anaplasma marginale in dogs. Ticks Tick Borne Dis 2018, 9:1302-9.

34. Wass L, Grankvist A, Bell-Sakyi L, Bergström M, Ulfhammer E, Lingblom C, Wennerås C: Cultivation of the causative agent of human neoehrlichiosis from clinical isolates identifies vascular endothelium as a target of infection. Emerg Microbes Infect 2019, 8:413-425.

35. Schouls LM, Van De Pol I, Rijpkema SGT, Schot CS: Detection and identification of Ehrlichia, Borrelia burgdorferi sensu lato, and Bartonella species in Dutch Ixodes ricinus ticks. J Clin Microbiol 1999, 37:2215-22.

36. Pan H, Liu S, Ma Y, Tong S, Sun Y: Ehrlichia-like organism gene found in small mammals in the suburban district of Guangzhou of China. Ann N Y Acad Sci 2003, 990:107-11.

37. Welinder-Olsson C, Kjellin E, Vaht K, Jacobsson S, Wennerås C: First case of human "Candidatus Neoehrlichia mikurensis" infection in a febrile patient with chronic lymphocytic leukemia. J Clin Microbiol 2010, 48:1956-9.

38. Portillo A, Santibáñez P, Palomar AM, Santibáñez S, Oteo JA: 'Candidatus Neoehrlichia mikurensis' in Europe. New Microbes New Infect 2018, 22:30-6.

39. Dugan VG, Gaydos JK, Stallknecht DE, Little SE, Beall AD, Mead DG, Hurd CC, Davidson WR: Detection of Ehrlichia spp. in Raccoons (Procyon lotor) from Georgia. Vector-Borne Zoonotic Dis 2005, 5:162-171.

40. Yabsley MJ, Murphy SM, Luttrell MP, Wilcox BR, Howerth EW, Munderloh UG: Characterization of "Candidatus Neoehrlichia lotoris" (family Anaplasmataceae) from raccoons (Procyon lotor). Int J Syst Evol Microbiol 2008, 58:2794-8.

41. Yabsley MJ, Murphy SM, Luttrell MP, Wilcox BR, Ruckdeschel C: Raccoons (Procyon lotor), but not rodents, are natural and experimental hosts for an ehrlichial organism related to “Candidatus Neoehrlichia mikurensis.” Vet Microbiol 2008, 131:301-8.

42. Hodžić A, Cézanne R, Duscher GG, Harl J, Glawischnig W, Fuehrer HP: Candidatus Neoehrlichia sp. in an Austrian fox is distinct from Candidatus Neoehrlichia mikurensis, but closer related to Candidatus Neoehrlichia lotoris. Parasit Vectors 2015, 8:1-4.

43. Hodžić A, Mitkovà B, Modrý D, Juránková J, Frgelecová L, Forejtek P, Steinbauer V, Duscher GG: A new case of the enigmatic Candidatus Neoehrlichia sp. (FU98) in a fox from the Czech Republic. Mol Cell Probes 2017, 31:59-60.

44. Hildebrand J, Buńkowska-Gawlik K, Adamczyk M, Gajda E, Merta D, Popiołek M, PerecMatysiak A: The occurrence of Anaplasmataceae in European populations of invasive carnivores. Ticks Tick Borne Dis 2018, 9:934-937 
45. Hornok S, Trauttwein K, Takács N, Hodžić A, Duscher GG, Kontschán J: Molecular analysis of Ixodes rugicollis, Candidatus Neoehrlichia sp. (FU98) and a novel Babesia genotype from a European badger (Meles meles). Ticks Tick Borne Dis 2017, 8:41-4.

46. Ćirović D, Milenković M: The first record of the free-ranging raccoon (Procyon lotor Linnaeus, 1758) in Yugoslavia. Mamm Biol 2003, 68:116-7.

47. Ćirovic D, Milenković M: Previous findings of the raccoon dog (Nycterentes procyonoides ussuriensis Matschie 1907) in Yugoslavia and analysis of probable paths of its immigration. Contrib to Zoogeography Ecol East Mediterr Reg 1999, 1:77-82.

48. Franke J, Hildebrandt A, Dorn W: Exploring gaps in our knowledge on Lyme borreliosis spirochaetes - Updates on complex heterogeneity, ecology, and pathogenicity. Ticks Tick Borne Dis 2013, 4:11-25.

49. Gern L, Estrada-Peña A, Frandsen F, Gray JS, Jaenson TGT, Jongejan F, Kahl O, Korenberg E, Mehl R, Nuttall PA: European reservoir hosts of Borrelia burgdorferi sensu lato. Zentralblatt fur Bakteriol 1998, 287:196-204.

50. Heidrich J, Schönberg A, Steuber S, Nöckler K, Schulze P, Voigt W-P, Schein E: Investigation of skin samples from Red Foxes (Vulpes vulpes) in Eastern Brandenburg (Germany) for the detection of Borrelia burgdorferi s.l. Zentralblatt für Bakteriol 1999, 289:666-72.

51. Dumitrache MO, Matei IA, Ionică AM, Kalmár Z, D’Amico G, Sikó-Barabási S, Ionescu DT, Gherman CM, Mihalca AD: Molecular detection of Anaplasma phagocytophilum and Borrelia burgdorferi sensu lato genospecies in red foxes (Vulpes vulpes) from Romania. Parasit Vectors 2015, 8:514.

52. Obrenović S, Ristanović E, Čekanac R, Radulović Ž, Ilić V. Seroprevalence of IgG antibodies against Borrelia burgdorferi in dogs in Belgrade area, Serbia. Acta Vet Beograd 2015, 65:99-110.

53. Potkonjak A, Savić S, Vračar V, Rnjak D, Tikvicki M, Obrenović S, Lako B: Prevalence of $\mathrm{G}$ class antibodies to antigens of lyme disease causes in dogs in Vojvodina, Serbia. Vet Glas 2013, 67:55-66.

54. Milutinović M, Masuzawa T, Tomanović S, Radulović Ž, Fukui T, Okamoto Y: Borrelia burgdorferi sensu lato, Anaplasma phagocytophilum, Francisella tularensis and their co-infections in host-seeking Ixodes ricinus ticks collected in Serbia. Exp Appl Acarol 2008, 45:171-83.

55. Tomanović S, Chochlakis D, Radulović Ž, Milutinović M, Ćakić S, Mihaljica D, Tselentis Y, Psaroulaki A: Analysis of pathogen co-occurrence in host-seeking adult hard ticks from Serbia. Exp Appl Acarol 2013, 59:367-376.

56. Rudenko N, Golovchenko M, Grubhoffer L, Oliver JH: Updates on Borrelia burgdorferi sensu lato complex with respect to public health. Ticks Tick Borne Dis 2011, 2:123-8.

57. Parola P, Roux V, Camicas JL, Baradji I, Brouqui P, Raoult D. Detection of ehrlichiae in African ticks by polymerase chain reaction. Trans R Soc Trop Med Hyg 2000, 94:707-8.

58. Masuzawa T, Komikado T, Iwaki A, Suzuki H, Kaneda K, Yanagihara Y. Characterization of Borrelia sp. isolated from Ixodes tanuki, I. turdus, and I. columnae in Japan by restriction fragment length polymorphism of $\operatorname{rrf}(5 \mathrm{~S})-\operatorname{rrl}(23 \mathrm{~S})$ intergenic spacer amplicons. FEMS Microbiol Lett 1996, 142: 77-83.

59. Regnery RL, Spruill CL, Plikaytis BD. Genotypic identification of rickettsiae and estimation of intraspecies sequence divergence for portions of two rickettsial genes. J Bacteriol 1991, 173(5):1576-89.

60. Spyridaki I, Gikas A, Kofteridis D, Psaroulaki A, Tselentis Y. Q fever in the Greek island of Crete: detection, isolation, and molecular identification of eight strains of Coxiella burnetii from clinical samples. J Clin Microbiol 1998, 36: 2063-2067. 
61. Sjöstedt A, Eriksson U, Berglund L, Tärnvik A. Detection of Francisella tularensis in ulcers of patients with tularemia by PCR. J Clin Microbiol 1997, 35: 1045-1048.

62. Rolain JM, Franc M, Davoust B, Raoult D. Molecular detection of Bartonella quintana, B. koeblerae, B. henselae, B. clarridgeiae, Rickettsia felis, and Wolbachia pipientis in cat fleas, France. Emerg Infect Dis 2003, 9(3):338-342.

\title{
CANDIDATUS NEOEHRLICHIA SP. (FU98) I BORRELIA BURGDORFERI SENSU LATO KOD CRVENIH LISICA (VULPES VULPES) IZ SRBIJE
}

\author{
SUKARA Ratko, JUWAID Salem, ĆIROVIĆ Duško, PENEZIĆ Aleksandra, \\ MIHALJICA Darko, VEINOVIĆ Gorana, RADOJIČIĆ Sonja, HODŽIĆ Adnan, \\ DUSCHER Gerhard Georg, TOMANOVIĆ Snežana
}

Aktivnosti ljudi kao što su krčenje šuma, urbanizacija i zagađenje životne sredine, dovode do smanjenja prostorne granice između divljih, domaćih životinja i ljudi. Ove aktivnosti povećavaju rizik za prelivanje patogena iz silvatičnog ciklusa u populacije domaćih životinja i ljudi. Lisice su prepoznate kao potencijalni rezervoari za brojne bakterijske patogene koji su važni sa aspekta humane i veterinarske medicine.

Cilj ove studije bio je da se utvrdi prisustvo i istraži prevalencija i prostorna distribucija bakterijskih patogena koji se prenose krpeljima u populaciji crvenih lisica iz Srbije, kao i da se analiziraju dobijeni rezultati sa epidemiološkog stanovišta. Analizirani su patogeni iz porodice Anaplasmataceae, Borrelia burgdorferi sensu lato (s.l.), Rickettsia spp., Coxiella burnetii, Francisella tularensis, Bartonella spp. Materijal za studiju su bile legalno odstreljene crvene lisice (Vulpes vulpes) poreklom sa 14 lokaliteta iz Srbije. Uzorci tkiva slezine od 129 životinja su testirani metodom konvencionalnog PCR-a na prisustvo bakterijskih patogena koji se prenose krpeljima.

Kod analiziranih životinja dokazano je prisustvo DNK sledećih bakterija: Candidatus Neoehrlichia sp. (FU98) kod šest životinja (4,7\%), B. burgdorferi sensu stricto kod jedne $(0,8 \%)$, B. lusitaniae kod dve $(1,6 \%)$ i B. garinii kod jedne životinje $(0,8 \%)$. Koinfekcija sa Candidatus Neoehrlichia sp. (FU98) i B. garinï potvrđena je kod jedne životinje. Svi uzorci su bili negativni na druge testirane krpeljima prenosive bakterijske patogene.

Rezultati ove studije ukazuju na potencijalnu ulogu lisica u prirodnim ciklusima kruženja Candidatus Neoehrlichia sp. (FU98) i uzročnika lajmske borelioze na istraživanom području. Potrebna su dalja istraživanja kako bi se rasvetlila uloga lisica u epidemiologiji ovih i drugih zoonotskih patogena koje prenose krpelji u Republici Srbiji. 